\title{
Identification and Histological Observation of Endophytic Fungi Isolated from Medicinal Plant, Physalis angulata L.
}

\author{
Utami Sri Hastuti*, Sulisetijono, Dwi Rahmawati, Ria Yustika Sari, Sugi Hartono, Chomisatut Thoyibah, Fitria Maulita, \\ Faiza Nur Imawati Ningsih, Siti Hartina Pratiwi
}

Microbiology Laboratory, Biology Department, Faculty of Mathematics and Natural Sciences, State University of Malang, Malang, Indonesia

\section{ARTICLE INFO}

\section{Article history:}

Received October 30, 2020

Received in revised form March 1, 2021

Accepted March 5, 2021

\section{KEYWORDS:}

Physalis angulata L., endophytic fungi,

identification,

histologic observation

\begin{abstract}
Some endophytic fungi species live in medicinal plant tissue and does not make any damage, but live in symbiotic mutualism relationship with the host plant. This research was done to: 1) identify the endophytic fungi species isolated from $P$. angulata leaf, twig, and stem bark tissues, 2) determine the endophytic fungi colonization in the $P$. angulata plant tissue by histologic observation. The endophytic fungi was isolated from healthy $P$. angulata plant parts, then inoculated on Potato Dextrose Agar medium and incubated in $27^{\circ} \mathrm{C}$ for $7-14$ days. Each endophytic fungi isolates were identified. The histologic observation was done by microscopic observation to determine the endophytic fungi position in the plant tissue. The conclusion are: 1) seven endophytic fungi species were found: Penicillium verrucosum, Colletotrichum alienum, Fusarium subglutinans, Aspergillus nidulans, Mycelia sterilia 1, Mycelia sterilia 2, and Rhizoctonia sp.; 2) the endophytic fungi micelium was found on the leaf epidermis cell wall, on the twig epidermis cell wall, and parenchyma cell wall, on the stem bark epidermis cell wall. The suggestion of the study: it is need to make the next research about secondary metabolites content produced by endophytic fungi species isolated from $P$. angulata and their antimicrobial activity.
\end{abstract}

\section{Introduction}

Physalis angulata L. Is a kind of medicinal plant. People use this plant to treat infection on gums, skin, intestine. This plant was cultivated for exploit as medicinal treatment purpose. The leaf and the stem parts of this plant contains: flavonoid, alkaloid, tannin, glycoside, and steroid (Nanumala et al. 2012). These compounds have antibacterial character, so this plant used in infection treatment.

Some medicinal plant live in symbiotic mutualism relationship with endophytic fungi that live in the plant tissues. The endophytic fungi does not cause any damage to the host plant, but could produce some antimicrobial secondary metabolites. The host plant protected from microbe infection by endophytic fungi antimicrobial secondary metabolites. The endophytic fungi also take some advantages through nutrients, protection from environmental stress (Clay

\footnotetext{
* Corresponding Author

E-mail Address: tuti_bio_um@yahoo.com
}

et al. 2002; Stanley et al. 2002; Kogel et al. 2006). The antimicrobial secondary metabolites produced by endophytic fungi species could be used as an antibiotic source. In the previous research it was found an endophytic fungi: Penicillium sp, isolated from Curcuma longa produced an antimicrobial compound (Singh et al. 2014). Another research proved that some endophytic fungi, i.e: Fusarium oxysporum, Rhizoctonia sp., Fusarium solani, Colletotrichum alienum, Colletotrichum ti, Colletotrichum aotearoa, Aspergillus parasiticus, Hansfordia biophila, Fusarium semitectum, Colletotrichum coccodes, and Colletotrichum gloeosporoides isolated from Hedychium acuminatum could produced antibacterial compounds: alkaloid, flavonoid, terpenoid, and tannin in the secondary metabolites (Hastuti et al. 2018). It is also proved that the secondary metabolites produced by those endophytic fungi species isolated from $H$. acuminantum have antimicrobial activity towards Staphylococcus aureus, and Bacillus subtilis (Hastuti et al. 2019b). The endophytic fungi live on the parenchyma cell wall and intercellular space of 
rhizome, epidermis, and parenchyma cell wall of leaf sheath, epidermis cell wall of $H$. acuminatum plant (Hastuti et al. 2018). The histologic observation can be use to observe the endophytic fungi colonization in plant tissues. The endophytic fungi could be isolated and identified to determined the species. This research was done to: 1 ) determine the endophytic fungi position in the $P$. angulata plant parts tissue by histologic observation; 2) identify the endophytic fungi species isolated from $P$. angulata bark, twig, and leaf.

\section{Materials and Methods}

\subsection{Material}

Physalis angulata plant parts: bark, twig, and leaf. The plant was taken from Balai Materia Medica, Batu, Malang in May 2019. Potato Dextrose Agar (PDA) medium from MERCK, 70\% alcohol, 95\% alcohol, $1 \% \mathrm{NaOCl}$, chloramphenicol, lactophenol, and lactophenol cotton blue.

\subsection{Methods}

2.2.1. Preparation of $P$ angulata Leaf, Twig, and Bark for Endophytic Fungi Position on the $P$ angulata Plant Tissue for Microscopic Observation

The bark, twig, and leaf of $P$. angulata were rinse with sterile destilled water, then slice in paradermal, transversal, and longitudinal section and made some microscopic slides. Then the endophytic fungi in the $P$. angulata plant tissue position were observed by microscopic histological observation.

\subsubsection{Endophytic Fungi Isolation Identification}

and

$P$. angulata bark, twig, and leaf were washed and soaked in $1 \% \mathrm{NaOCl}$ during $1 \mathrm{~min}$., then washed with sterilized water. Afterward soaked in $70 \%$ alcohol during $1 \mathrm{~min}$. And washed again with sterilized water (Gangadewi et al. 2008). The leaf were cutted in $1 \mathrm{x}$ $1 \mathrm{~cm}^{2}$ each, the twig and the bark were cutted in the thickness of $0.5 \mathrm{~cm}$ each. Afterwards each samples were inoculated on PDA plate medium contains chloramphenicol $(100 \mathrm{mg} / \mathrm{l})$ and incubated in $27^{\circ} \mathrm{C}$ during 7-14 days for endophytic fungi isolation. Each fungi isolates were made slide culture for microscopic observation and afterwards the fungi characters were refer to the fungi identification book for each isolate identification need. The identification books are: Pictorial Atlas of Soil and Seed FungiMorphologies of Cultured Fungi and Key to Species by: Tsuneo Watanabe 2002. CRC Press: Florida, Fungi, and Food Spoilage by John I. Pitt and Ailsa D. Hocking. 1985. Academic Press: Tokyo, Illustrated Genera of Imperfect Fungi by: H. L. Barnett and Barry B. Hunter. 1972. Burgess Publishing Company: Minesota.

\section{Results}

\subsection{TheHistologicalObservation of Endophytic Fungi on Physalis angulata Leaf, Twig, and Bark Colonization}

The colonization of endophytic fungi in $P$. angulata tissues was observed microscopically. The endophytic fungi species were found in bark, twig, and leaf of $P$. angulata. The fungi mycellium was found on the bark epidermis cell wall (Figure 1a), on the leaf epidermis cell wall (Figure 1b) and on the leaf parenchyme cell wall (Figure 1c), on the leaf spongy cell wall (Figure 1d).

The endophytic mycelium was found on the epidermis cell wall in bark, twig, and leaf of $P$. angulata, but it is also found on the leaf spongy cell wall. This result shows that the endophytic fungi were not only found on the leaf but also found in another plant's part, i.e: twig and bark of $P$. angulata plant. In another research the endophytic fungi found in rhizome, leaf, and leaf sheath of Hedychium acuminatum plant. Based on the histological observation it was found that there are no mycelium inserted into cell cytoplasm, so the mycelium does not make any damage to the plant tissue. That is why the host plant still in healthy condition.

\subsection{The Identification Result of Endophytic Fungi Isolated from Physalis angulata}

Seven endophytic fungi species was found in $P$. angulata bark, twig, and leaf. There are: Penicillium verrucosum, Colletotrichum alienum, Fusarium subglutinans, Aspergillus nidulans, Mycelia sterilia 1, Mycelia sterilia 2, and Rhizoctonia sp. Figure 2. shows the seven endophytic fungi colonies.

The characteristic description of each endophytic fungi isolates described in Table 1. There were variation in fungi colony colour, i.e: green, whitish orange, white, greyish white, brown and black. The colony characters were velvety and the other are cottony. There were variation in conidia shape i.e: subspheroid, cylindrical, fusiform, and slightly 
curved. Penicillium verrucosum had subspheroid conidia shape with smooth walled. Aspergillus nidulans had sphaerical conidia shape with roughened wall. Colletotrichum alienum also had conidia as reproduction organ in cylindrical with round edge shape and smooth walled. C. alienum
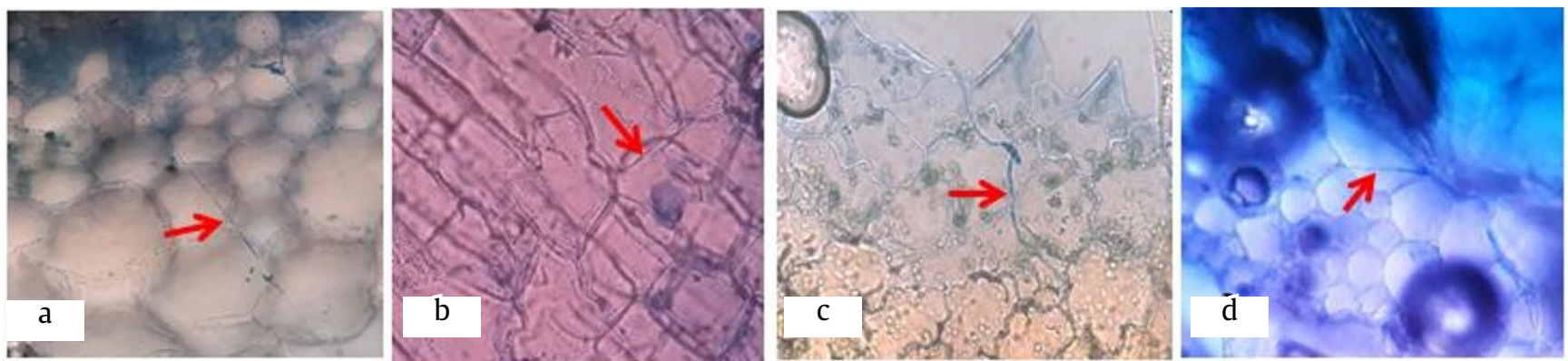

Figure 1. The histological observation of endophytic fungi position on Pysalis angulata tissues. (a) On the bark epidermis cell wall (arrow), (b) on the twig epidermis cell wall, (c) on the leaf epidermis cell wall (arrow), (d) on the leaf spongy cell wall
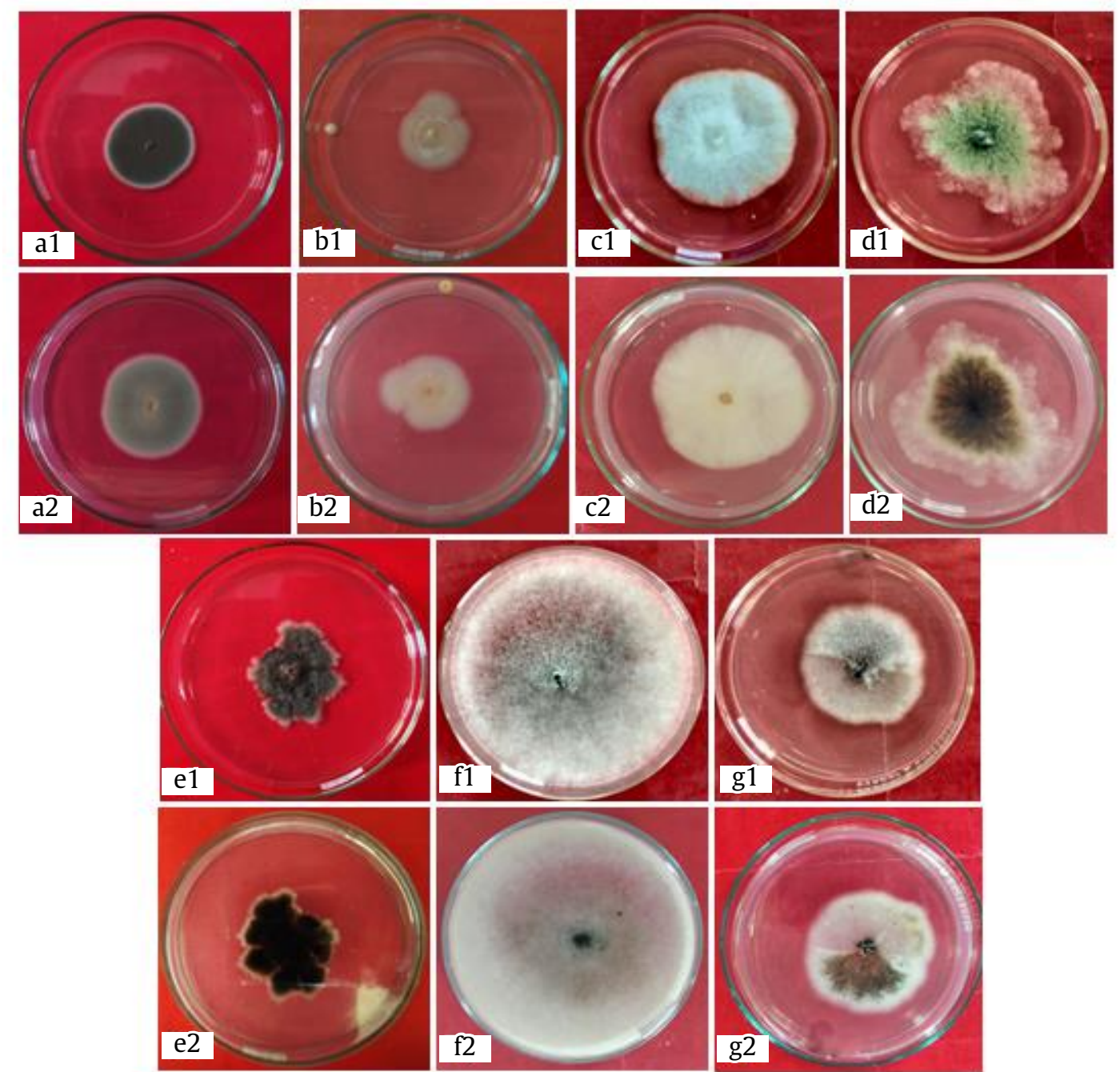

Figure 2. The endophytic fungi colonies on PDA medium after 7 days incubation. 1: upper, 2: reverse (a) Penicillium verrucosum, (b) Colletotrichum alienum, (c) Fusarium subglutinans, (d) Aspergillus nidulas, (e) Mycelia sterilia 1, (f) Mycelia sterilia 2, (g) Rhizoctonia sp. 


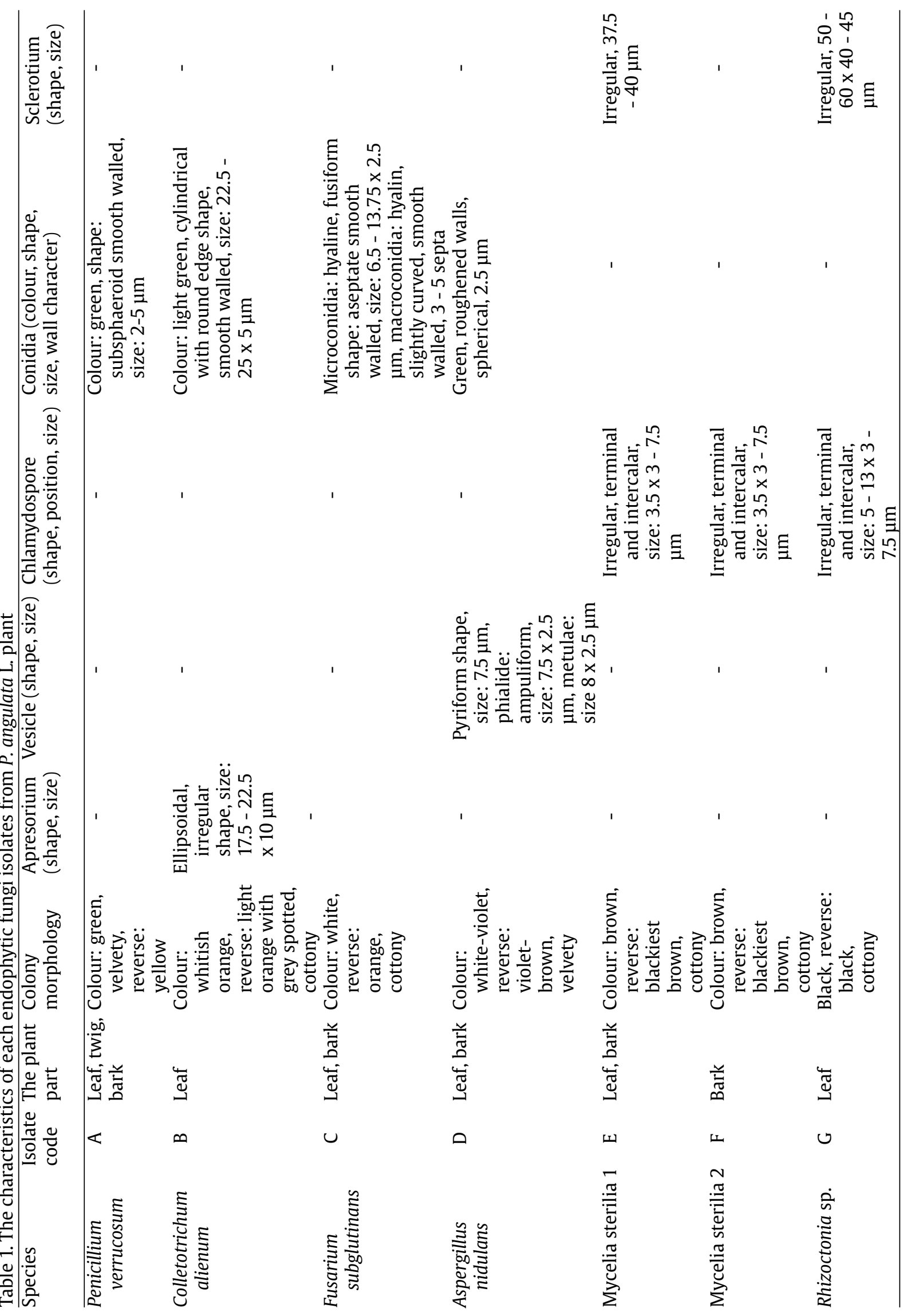


also have appresorium with cylindrical and irregular shape. Fusarium subglutinans have fusiform shape microconidia and slightly curved shape macroconidia. Mycelia sterilia do not have conidia. This fungi have sclerotium, a compacted mass of mycelium.

\section{Discussion}

The research result shows that it was found seven endophytic fungi species isolated from $P$. angulata bark, twig, and leaf, i.e: P. verrucosum, C. alienum, $F$. subglutinans, A. nidulans, Mycelia sterilia 1, Mycelia sterilia 2, and Rhizoctonia sp. These endophytic fungi species could be found only in leaf, but certain species also found in leaf, as well as in bark and twig of $P$. angulata. In previous research about endophytic fungi in medicinal plant Withania somnifera shows that 20 endophytic fungi species have been isolated from the leaf, stem, and root parts (Khan et al. 2010). In another research were proved that 9 endophytic fungi species were found in leaf, twig, and flower petal of Cananga odorata plant (Hastuti et al. 2019a). These research results proved that endophytic fungi could be found in different or same plant parts.

This research shows that each endophytic fungi species live in $P$. angulata as the host plant in healthy condition. It is proved that there is mutualistic symbiosis relationship between each endophytic fungi and $P$. angulata plant as the host plant. In previous research it was found that each endophytic fungi species could produce some antimicrobial metabolites. This fact showed that the endophytic fungi could protect the host plant from bacterial infection. The endophytic fungi play an important role in the host plant protection from insects, pests, and herbivore (Khan et al. 2010). On the other way, the fungi also receive nutrition, and also protected from harmfull environment factors, such as: high air temperature, low humidity, etc (Clay et al. 2002; Stanley et al. 2002; Kogel et al. 2006).

The seven endophytic fungi were isolated from healthy $P$. angulata plant parts. In histological observation result, it also proved that there are no mycelium inserted in to cell cytoplasm and the fungi does not make any damage to the plant tissue. This fact shows that endophytic fungi which colonize living, internal tissues of the plant does not cause any harm to their host plant. There are a symbiotic mutualism interaction between endophytic fungi and $P$. angulata plant.

Some endophytic fungi species isolated from $P$. angulata plant could be found in another plant. Colletotrichum alienum also found as one of the endophytic fungi species isolated from Hedycium acuminatum (Hastuti et al. 2018), from Cananga odorata (Hastuti et al. 2019a). Another species of Colletotrichum have been isolated from Piper nigrum, i.e: Colletotrichum gloeosporoides (Chitra et al. 2014), in tomato fruit, i.e: Colletotrichum acutatum (Zivkovic et al. 2010). Fusarium spp. could found as endophytic fungi in another plant. Fusarium nivale and Fusarium solani were found in Dendrobium crumenatum Sw. (Mangunwardoyo et al. 2012). F. semitectum were found in Talinum paniculatum leaf (Hastuti et al. 2015). Mycelia sterilia oftenly found in medicinal plant. This endophytic fungi found in Chinese medicinal plant (Huang et al. 2008). It is need to make the next research about secondary metabolites content produced by endophytic fungi species isolated from $P$. angulata and their antimicrobial activity.

\section{Conclusion}

This research result proved that: 1) seven endophytic fungi species were found in $P$. angulata plant, i.e: Penicillium verrucosum, Colletotrichum alienum, Fusarium subglutinans, Aspergillus nidulans, Mycelia sterilia 1, Mycelia sterilia 2, and Rhizoctonia sp. Each fungi species could be found in the leaf, twig, and bark parts of $P$. agulata plant. It shows the diversity of endophytic fungi species isolated from $P$. angulata plant; 2) the seven endophytic fungi were found on the bark epidermis cell wall, on the twig epidermis cell wall, on the leaf epidermis cell wall, and on the spongy cell wall of $P$. angulata plant. It shows that the endophytic fungi could be found in some plant parts. For the suggestion, it is need to make the next research about secondary metabolites content produced by endophytic fungi species isolated from $P$. angulata plant and their antimicrobial activity.

\section{Acknowledgements}

We are gratefull to Balai Materia Medica, Batu, Malang for preparing $P$. angulata plant as the research material. 


\section{References}

Chitra S et al. 2014. Piperine production by endophytic fungus Colletotrichum gloeosporioides isolated from Piper nigrum. Phytomedicine: International Journal of Phytopharmacology 21:534-540.

Clay K, Schardl CL. 2002. Evolutionary origins and ecological consequences of endophyte symbiosis with grasses. American Naturalist 160:99-127.

Gangadewi V, Muthumary J. 2008. Isolation of Colletotrichum gloeosporioides, a moved endophytictaxol-producing fungus from the leaves of a medicinal plant, justicia gendarussa. Mycologia Balcanica 5:1-4.

Hastuti US et al. 2015. Identification and Histologic Observation of Endophytic Fungi Isolated from A Medicinal Plant, Talinum paniculatum (Jacq.) Gaertn. Presented in The 5th International Conference on Biological Science in Yogyakarta.

Hastuti US et al. 2018. Observation, identification, and secondary metabolites analysis of endophytic fungi isolated from a medicinal plant, Hedychium acuminatum Roscoe. AIP Conference Proceedings 2002:020070 DOI:10.1063/1.5050166

Hastuti US et al. 2019a. Histologic observation, identification and secondary metabolites analysis of endophytic fungi isolated from Cananga odorata (Lam.) Hook $\mathrm{F}$ and Thomson. IOP Conf Series: Materials Science and Engineering 546:022005. DOI:10.1088/1757$899 X / 546 / 2 / 022005$

Hastuti US et al. 2019b. Antimicrobial activity of endophytic fungi isolated from a medicinal plant, Hedychium acuminatum Roscoe. AIP Conference Proceedings 2002:020070 DOI:10.1063/1.5061895
Huang WY et al. 2008. Biodiversity of endophytic fungi associated with 29 traditional Chinese Medicinal plants. Fungal Diversity 33:61-75.

Khan $\mathrm{R}$ et al. 2010. Communities of endophytic fungi in medicinal plant Withania somnifera. Pak J Bot 42:1281-1287.

Kogel KH et al. 2006. Endophyte or parasite- what decides? Current Opinion in Plant Biology 9:358-363.

Mangunwardoyo Wet al. 2012. Frequency of endophytic fungi isolated from Dendrobium crumenatum Sw. (Pigeon orchid) and antimicrobial activity. J Biodiversitas 13:34-39.

Nanumala SK et al. 2012. Anti ulcer activity of the ethanolic extract of leaves Physalis angulata L. Int J Pharm Sci $4: 226-228$.

Singh D et al. 2014. Optimization and characterization of silver nanoparticle by endophytic fungi Penicillium sp. isolated from Curcuma longa (Turmeric) and application studies against MDR E. coli and S. aureus. Journal of Bioorganic Chemistry and Application 2014:1-8.

Stanley HF, William FF. 2002. Fungal endophytes: common host plant symbionts but uncommon mutualists. Integration and Comparative Biology. 42:360-368.

Zivkovic S et al. 2010. Morphological and molecular identification of Colletotrichum acutatum from tomato fruit. Pestic Phytomed (Belgrade) 23:231-239. 